\title{
Pengembangan Potensi Produk Lokal Pada Penyandang Disabiltas Dalam Industri Pariwisata Daerah Kecamatan Belinyu Bangka
}

\author{
Yang Gusti Feriyanti ${ }^{1 *}$, Herwan ${ }^{2}$ \\ ${ }^{1,2}$ Stisipol Pahlawan 12 Bangka Belitung, Indonesia \\ email : yanggoe5@gmail.com
}

\begin{abstract}
This research aims to assist the government to develop Bangka Belitung Regency into a tourism center due to its rich natural resources order to change the way of life of its people from relying on tin mining and other industries for their wellbeing. In addition to its rich natural resources, Belinyu Bangka is also known for its culinary product variants capable of supporting the tourism sector. Tourism is one of the engines of the world economy that contributes to the prosperity of a country due to the existence of natural resources which provides great employment opportunities for its citizens. It is hoped that the products produced are made into independent businesses and with economic values in order to help reduce labor problems. There needs to be a two-way coordination and communication effort between stakeholders and business organizations for unemployed people to become empowered and with the opportunity to become independent entrepreneurs. This research was conducted at the Extraordinary School Jl. Bukit Jukung, Belinyu sub-district, Bangka Regency from June to October 2019 with data obtained from the Extraordinary Schools, Belinyu District.
\end{abstract}

Keywords : Development, Disability, Local Product Variant.

Abstrak: Penelitian ini bertujuan untuk membantu Pemerintah untuk mengembangkan kabupaten Bangka Belitung menjadi pusat pariwisata karena sumber daya alamnya yang kaya serta untuk mengubah cara hidup rakyatnya dari mengandalkan pertambangan timah dan industrilainnya untuk kesejahteraan mereka. Selain sumber daya alamnya yang kaya, Belinyu Bangka juga dikenal dengan varian produk kulinernya yang mampu mendukung sektor pariwisata. Pariwisata adalah salah satu mesin perekonomian dunia yang berkontribusi pada kemakmuran suatu Negara karena keberadaan sumber daya alam yang memberikan peluang kerja yang besar bagi warganya diharapkan bahwa produk yang dihasilkan dibuat menjadi bisnis Independen dan dengan nilai ekonomi untuk membantu mengurangi masalah ketenagakerjaan. Perlu ada upaya dan koordinasi dan komunikasi dua arah antara pemangku kepentingan dan organisasi bisnis agar orangorang yang menganggur dapat diberdayakan dan dengan kesempatan menjadi wirausahawan mandiri. Penelitian ini dilakukan di sekolah Luar Biasa Jalan Bukit Jukung kecamatan belinyu, Kabupaten Bangka dari Juni hingga Oktober 2019 dengan data yang diperoleh dari sekolah luar biasa, kecamatan Belinyu

Kata Kunci: Pengembangan, Disabilitas, varian Produk lokal

Copyright (c) 2021 The Authors. This is an open access article under the CC BY-SA 4.0 license (https://creativecommons.org/licenses/by-sa/4.0/)

\section{PENDAHULUAN}

Pengembangan Industri Pariwisata di kepulauan Bangka Belitung saat ini sangat diupayakan oleh pemerintah daerah, karena melalui industri pariwisata 
diharapkan dapat meningkatkan pendapatan serta perbaikan ekonomi masyarakat kabupaten Bangka yang selama ini mengandalkan sektor pertambangan. Pariwisata merupakan bagian yang tidak terpisahkan dari kegiatan kehidupan manusia yang berhubungan dengan permasalahan social dan ekonomi. Salah satu dari tujuan pariwisata adalah adanya upaya untuk melestarikan alam, lingkungan hidup melalui partisipasi masyarakat (SDM) dalam menciptakan kegiatan ekonomi untuk peningkatan taraf hidup mereka.

Melalui kegiatan pariwisata masyarakat lokal dilibatkan untuk berpartisipasi dalam pembangunan serta pemberdayaan sumber daya manusia agar lebih memahami nilai-nilai lokal yang sudah ada. hasil kekayaan alam yang merupakan asset suatu daerah yang dapat dikembangkan menjadi nilai ekonomis, menciptakan peluang kerja serta kualitas hidup masyarakat. Selama ini masyarakat Belinyu hanya mengandalkan hasil kekayaan alam yaitu pertambangan timah sebagai penunjang kehidupan perekonomian mereka. Kekayaan alam tanah di kabupaten Bangka yang menghasilkan biji timah merupakan polemik bagi Pemerintah serta kehidupan masyarakat Babel.issue tentang kerusakan lingkungan dan kondisi perekonomian masyarakat Babel merupakan salah satu upaya pemerintah untuk mengubah pola pikir masyarakat babel dalam mengembangkan industri lainnya salah satunya adalah sektor pariwisata.

Pengembangan wisata selain sektor pertambangan yang selama ini merupakan produk dan hasil utama perekonomian masyarakat kepulauan Bangka Belitung merupakan upaya dan strategi pemerintah untuk melakukan transformasi bagi masyarakat setempat untuk beralih dari pertambangan kepariwisata, mengingat potensi alam ,sumber daya manusia dan produk local yang dihasilkan dapat pula dijadikan salah satu alternative untuk menyerap lapangan pekerjaan bagi masyarakat Babel yang selama ini hanya mengharapkan pertambangan Timah sebagai hasil unggulan dan mata pencaharian mereka selama ini.

Beralihnya industri pertambangan ke industri pariwisata diharapkan mampu menyerapkan tenaga kerja selain ramah lingkungan juga dapat memberikan peluang pengembangan wirausaha bagi masyarakat agar potensi-potensi alam dapat dilestarikan serta dapat menciptakan kreatifitas masyarakat Babel khususnya di Belinyu. 
Daerah wisata yang memiliki potensi untuk dikembangkan di kabupaten Bangka adalah kecamatan belinyu yang terletak di bagian utara kabupaten Bangka. Dinamika kehidupan masyarakat belinyu yang telah berbaur dengan berbagai suku budaya seperti etnis Tionghoa, factor social ekonomi memberikan keunikan sendiri. Kegiatan ekonomi masyarakat belinyu lebih banyak dikelola oleh etnis Tionghoa, dengan berbekal jiwa wirausaha maka masyarakat etnis Tionghoa mampu membangun pusat-pusat pertokoaan. Selain pusat-pusat pertokoaan yang menjual sandang dan pangan belinyu juga terkenal dengan daerah wisata yang saat ini belum banyak dikelola dengan baik oleh pemerintah daerah maupun masyarakat setempat.

Banyaknya pusat-pusat pertokoan ini tentu saja memberikan peluang kerja bagi masyarakat serta kesempatan untuk mengembangkan kewirausahaan dalam mengelola sumberdaya alam. Melalui keterlibatan nmasyarakat dalam peluang kerja ini diharapkan dapat memberikan perubah antara hidup masyarakat serta dapat membawa perubahan dalam kehidupan social ekonomi masyarakat. Terbukanya peluang tenaga kerja pada masyarakat local dapat juga diterapkan dalam sektor pariwisata. Prospek yang ditawarkan sangat banyak dalam dunia pariwisata salah satunya adalah pengelolaan kawasan wisata dan hospitality.

Salah satu destinasi yang menarik dikunjungi adalah daerah pariwisata Belinyu yang terletak di bagian Utara Babel. keindahan pulau mentigi dan pulau putri yang berdekatan dengan pantai penyusuk,serta pesona pasir putih dengan birunya laut yang dikelilingi bebatuan yang besar memberikan pesona eksotik tersendiri bagi masyarakat Belinyu maupun wisatawan luar dari kepulauan Bangka Belitung ini. Besarnya potensi wisata yang ada di Belinyu belum mendapat pengelolaan yang optimal karena selama ini hanya pelaku-pelaku usaha konvensional yang dilibatkan serta belum banyak dikelola secara eksklusif, padahal berbicara masalah pengembangan wisata bukan persoalan kekayaan alam saja tetapi banyak potensi lainnya seperti pemberdayaan masyarakat produk-produk unik local yang merupakan pesona tersendiri dan daya tarik yang nantinya akan menarik minat wisatawan untuk datang dan kembali mengunjungi destinasi wisata. Berbicara tentang pemberdayaan masyarakat hal ini juga seharusnya berlaku pada penyandang disabilitas, karena mereka juga bagian dari masyarakat yang memiliki hak dan kewajiban yang sama sebagai warga Negara. 
Penyandang disabilitas adalah orang yang mengalami hambatan dalam melakukan interaksi dengan lingkungan akibat adanya keterbataan fisik, mental, intelektual atau indera (Pusat Studi Layanan Disabilitas, 2014:15). Selain itu penyandang disabilitas juga bisa disebut orang yang rentan seperti wanita hamil, anak-anak, korban bencana alam, dan korban bencana social.

Belum maksimalnya keterlibatan penyandang disabilitas dengan ketersediaan lapangan pekerjaan merupakan masalah yang harus dipikirkan oleh pihak-pihak terkait untuk menggerakkan sektor industri lainnya khususnya di bidang pariwisata. Jenis usaha pariwisata tentu saja dapat memberikan kesempatan yang besar kepada penyandang disabilitas seperti adanya peluang pemberdayaan sumber daya manusia melalui ketersediaan lapangan pekerjaan. Stigma masyarakat yang menganggap bahwa penyandang disabilitas adalah orang-orang idiot dan memiliki keterbelakangan mental yang tidak normal merupakan suatu bentuk diskriminasi dan berdampak pada kehidupan social dan psikologi mereka sebagai mahluk social yang butuh penghargaan dan penerimaan di dalam kehidupan bermasyarakat.

Di Belinyu terdapat Sekolah Luar Biasa (SLB) Air Jukung yang merupakan salahsatu sekolah yang memberikan kesempatan kepada anak-anak disabilitas untuk belajar seperti sekolah regular lainnya, hanya saja kurikulum pembelajaran yang diberikan berbeda dengan sekolah informal lainnya. Penyandang disabilitas ini diberikan ketrampilan tangan untuk mengasah hard skill mereka, dengan harapan kelak penyandang disabilitas dapat mandiridan bekerja bahkan bisa membuka peluang pekerjaan bagi orang lain. Ada beberapa produk yang sudah dihasilkan dibawah pelatihan para Guru-guru yang sudah mengajarkan ketrampilan kepada para penyandang disabilitas

Dari beberapa produk yang dihasilkan oleh mereka sudah pernah diikut sertakan dalam pameran berskala kecil, hanya saja berdasarkan fakta lapangan kebanyakan produk yang diminati adalah hasil makanan olahan lokal/kuliner. Seperti makanan khas berbahan ikan seperti rusep, getas/keletek, otak-otak, kumpangcai, terasi/belacan, kemplang panggang, sirup es jeruk kunci, asinan klubi. Pengolahannya yang unik memberikan cita rasa tersendiri serta memberi peluang untuk dijadikan industry kreatif agar memiliki nilai jual ekonomis. 
Pemberdayaan ini sangat penting dilakukan mengingat bahwa anak-anak SLB pun harus dipersiapkan mandiri sehingga kelak mereka tidak bergantung kepada orang lain serta dapat memenuhi kebutuhan hidupnya, memberikan konstribusi dalam kehidupan bermasyarakat dan tidak menutup kemungkinan bahwa merekapun dapat memberikan kehidupan yang layak bagi orang lain.

Persoalannya adalah adanya diskriminasi dan stigma negative terhadap penyandang disabilitas oleh masyarakat dan pelaku usaha tidak memberikan kesempatan kepada disabilitas untuk mengembangkan potensi mereka agar dapat mandiri. Keterbatasan fisik yang mereka miliki menghambat mereka untuk berkreasi padahal melalui pelatihan merekapun dapat dikaryakan dan dapat memberikan peluang kerja. Kurangnya koordinasi dan komunikasi antara pemerintah serta pelaku bisnis merupakan kendala sehingga stigma bahwa disabilitas tidak mampu bekerja di sector informal maupun formil harus disingkirkan.

Penekanannya adalah bagaimana pihak-pihak eksternal dalam hal ini para pelaku bisnis pariwisata dapat memperdayakan penyandang disabilitas yang sudah memiliki ketrampilan untuk mandiri bahkan sudah menghasilkan varian-varian produk yang mereka buat agar tercipta lapangan pekerjaan dan dapat menjadi daya tarik bagi para wisatawan lokal maupun asing agar pariwisata sebagai leading sector dan core business yang memiliki keterkaitan dengan ekonomi dan social yang besar dapat dikembangkan menjadipotensi wisata yang berkelanjutan bagi suatu daerah.

Dari permasalahan awal di atas yang peneliti jelaskan sangat menarik apabila antara bisnis pariwisawa, pemberdayaan penyadang disabilitas dan varianvarian produk local yang dihasilkan dapat disandingkan secara harmonis agar dapat dijadikan ladang bisnis bagi penyandang disabilitas dan masyarakat, agar mereka termotivasi untuk mandiri dan menjadi wirausahawan baru yang dapat membuka peluang usaha dan lapangan pekerjaan bagi dirinya dan bahkan untuk orang lain. Pariwisata dan ekonomi kreatif saling berpengaruh dan dapat saling bersinergi jika dikelola dengan baik. Kegiatan wisata dipengaruhi oleh 3 (tiga) faktor, yaitu : pertama, something to see; Kedua something to do; dan ketiga something to buy. Something to see terkait dengan atraksi di daerah tujuan wisata, something to do terkait dengan aktivitas wisatawan di daerah tujuan wisata, sementara something to 
buy terkait dengan souvenir khas yang dibeli di daerah tujuan wisata sebagai cindera mata yang bisa dibawa pulang. Dalam ketiga komponen tersebut, ekonomi kreatif dapat masuk melalui something to buy dengan menciptakan produk-produk inovatif khas suatu daerah tujuan wisata.

\section{METODE}

Metode dalam penelitian ini secara umum memanfaatkan desain penelitian deskriptif kualitatif dengan pendekatan penelitian yang dipilih oleh peneliti dengan mengamati, mengumpulkan informasi dan menyajikan analisis hasil penelitian dimana pengukurannya dilakukan secara objektif atau apa adanya. Sifat penelitian ini lebih cenderung bersifat eksploratif dalam hal ini untuk memberikan pemetaan dan pemahaman komunikasi kreatif, pemetaan potensi ekonomi kreatif dan pemberdayaan penyandang disabilitas dengan varian-varian produk yang telah mereka buat. Penelitian ini membuka kemungkinan penggunaan metode yang lainnya. Moleong ( 2004:13 ) mengemukakan karakteristik pendekatan kualitatif menggunakan latar alamiah, menggunakan manusia sebagai instrument utama, menggunakan metode kualitatif (pengamatan, wawancara, atau studi dokumen) untuk menjaring data, menganalisis data secara deskriptif dan induktif. Metode deskriptif-kualitatif tidak jarang melahirkan apa yang disebut Seltiiz, Wrightsman, dan Cook ( dalam Rakhmat,2002) sebagai penelitian yang insightmulating, yakni peneliti terjun langsung ke lapangan tanpa dibebani atau diarahkan oleh teori. Ia bebas mengamati objeknya, menjelajah dan menemukan wawasan - wawasan baru sepanjang penelitian. Penelitian ini dilakukan dari bulan Juni sampai dengan Oktober 2019 dengan mengambil lokasi penelitian di SLB Air Jukung Belinyu Bangka.Untuk mendapatkan data prapenelitian, maka dilakukan observasi dan wawancara dengan Guru-guru ketrampilan serta murid SLB Air Jukung.jumlahinforman yang peneliti pilih adalah sebanyak 15 orang yang terdiri dari 4 Guru dan 11 Siswa SLB yang memiliki ketrampilan membuat kerajinan tangan serta telah banyak melakukan pameran penjualan varian-varian produk lokal yang dihasilkan selama mendapatkan pelatihan dari guru-guru SLB.

\section{HASIL DAN PEMBAHASAN}

Berdasarkan hasil observasi dan catatan lapangan yang peneliti lakukan di objek penelitian SLB Air Jukung Belinyu yang tujuannya untuk mengetahui 
aktivitas dan melihat hasil kreativitas siswa disabilitas SLB Air Jukung. Hasil wawancara dengan kepala sekolah SLB Air Jukung Ibu Rika Perawati plt yang menggantikan posisi ibu Lena, beliau menyatakan bahwa selama ini sudah ada upaya memberikan pelatihan kepada siswa-siswi SLB untuk membuat ketrampilan kerajinan tangan seperti lukisan, sulaman untuk tempat tissue dan hasil jahitan baju serta celana yang menggunakan bahan bekas pakai kain perca,hanya saja produkproduk yang dihasilkan masih skala kecil sesuai dengan permintaan, dan hasil kerajinan tangan tersebut terkadang diikut sertakan dalam pameran lokal yang diadakan secara sederhana di lingkungan sekolah. Peneliti diajak oleh Guru-guru SLB untuk melihat hasil karya disabilitas yang telah dipasarkan seperti payung warna-warni, lukisan,tempat tissue,taplak meja hasil sulaman, sandal jepit dan makanan ringan seperti kue serta celana pendek dari bahan perca.Payung warna warni merupakan hasil kreasi dari bimbingan salah satu guru yang memberikan pelatihan keterampilan untuk siswa-siswi SLB dan dihasilkan oleh kelas tuna grahita.

Sebelumnya hasil karya anak-anak SLB sudah banyak diperjualkan kepada masyarakat melalui pameran kecil apabila ada event-event nasional seperti perayaan 17 Agustus dan bazar hanya saja terkendala dengan masalah promosi dan pemasaran.varian produk-produk yang dihasilkan juga sudah bervariasi.setiap siswa-siswi memiliki ketrampilan dan menghasilkan karya yang berbeda, hal ini sebagai salah satu strategi yang dilakukan oleh Guru-guru SLB untuk memberikan ketrampilan dan kemandirian agar kelak para siswa-siswi dapat belajar mandiri dan berwiraswasta untuk dapat menghasilkan nilai ekonomi bagi kehidupan mereka.Kendala yang terjadi adalah belum ada promosi untuk memasarkan produk yang sudah dihasilkan serta memperkenalkan kepada masyarakat agar produkproduk tersebut dapat diminati serta memberikan nilai jual. Sehubungan dengan permasalahan tersebut mereka hanya sekedar untuk membuat hasil karya saja tetapi belum bisa memasarkan secara maksimal.

Belinyu memiliki beberapa tempat pariwisata yang sangat potensial seperti wisata pantai, budaya dan kulinernya. Pada saat ini wisata pantai merupakan bagian dari mata pencaharian masyarakat belinyu, salah satunya adalah pantai penyusuk dan pantai levar. Pantai penyusuk yang terkenal dengan bebatuan granitnya 
memiliki keindahan dan keunikan tersendiri bagi para wisatawan khususnya wisatawan lokal. Pantai penyusuk juga diapit oleh pulau putri yang terkenal dengan keindahan alam dan pasirnya yang putih serta airnya yang jernih sehingga lokasi wisata ini dijadikan program pengembangan wisata karena mulai banyak diminati oleh wisatawan lokal maupun luar daerah. Pengembangan dan pengelolaannya masih mengandalkan partisipasi swadaya masyarakat dengan minim infrastruktur, seperti penyediaan toilet seadanya,tempat beribadah dan kios untuk menjajakan makanan dan minuman masih menggunakan pondok yang terbuat dari kayu dan atap rumbia. Hal yang sama terjadi dengan pengelolaan pantai levar yang saat ini sedang mempromosikan wisata pantai melalui media sosial dan mengikuti ajang festival karang lintang. Pengelolaan yang dilakukan oleh kelompok pemuda greenboy hanya terbatas pada membersihkan pantai dan mengadakan event-event skala kecil untuk menarik minat masyarakat untuk berkunjung ke objek wisata tersebut. Selama ini kegiatan pariwisata di belinyu masih dikelola secara konvensional yaitu hanya mengandalkan partisipasi masyarakat dengan mengumpulkan dana dari pengunjung lokal yang berkunjung ke pantai. Sementara akses untuk mendukung pariwisata belum memadai seperti tempat parkir, toilet, ibadah dan penjualan produk-produk pariwisata belum banyak diperjual belikan di objek wisata tersebut. Sebagaian besar wisatawan yang berkunjung ke pantai levar dan penyusuk adalah wisatawan lokal dari beberapa wilayah seperti dari sungailiat dan pangkal pinang,hal ini membuktikan bahwa objek wisata di Belinyu mulai diminati oleh wisatawan lokal sehingga memberikan potensi bahwa pariwisata di kecamatan Belinyu dapat berkembang menjadi objek wisata favourite apabila dikelola dengan baik.Berikut hasil karya dari penyandang disable yang peneliti peroleh dari hasil observasi dan dokumentasi. Produk - produk ini merupakan hasil pelatihan dan ketrampilan yang telah diajarkan oleh guru-guru Sekolah Luar Biasa Air Jukung : 

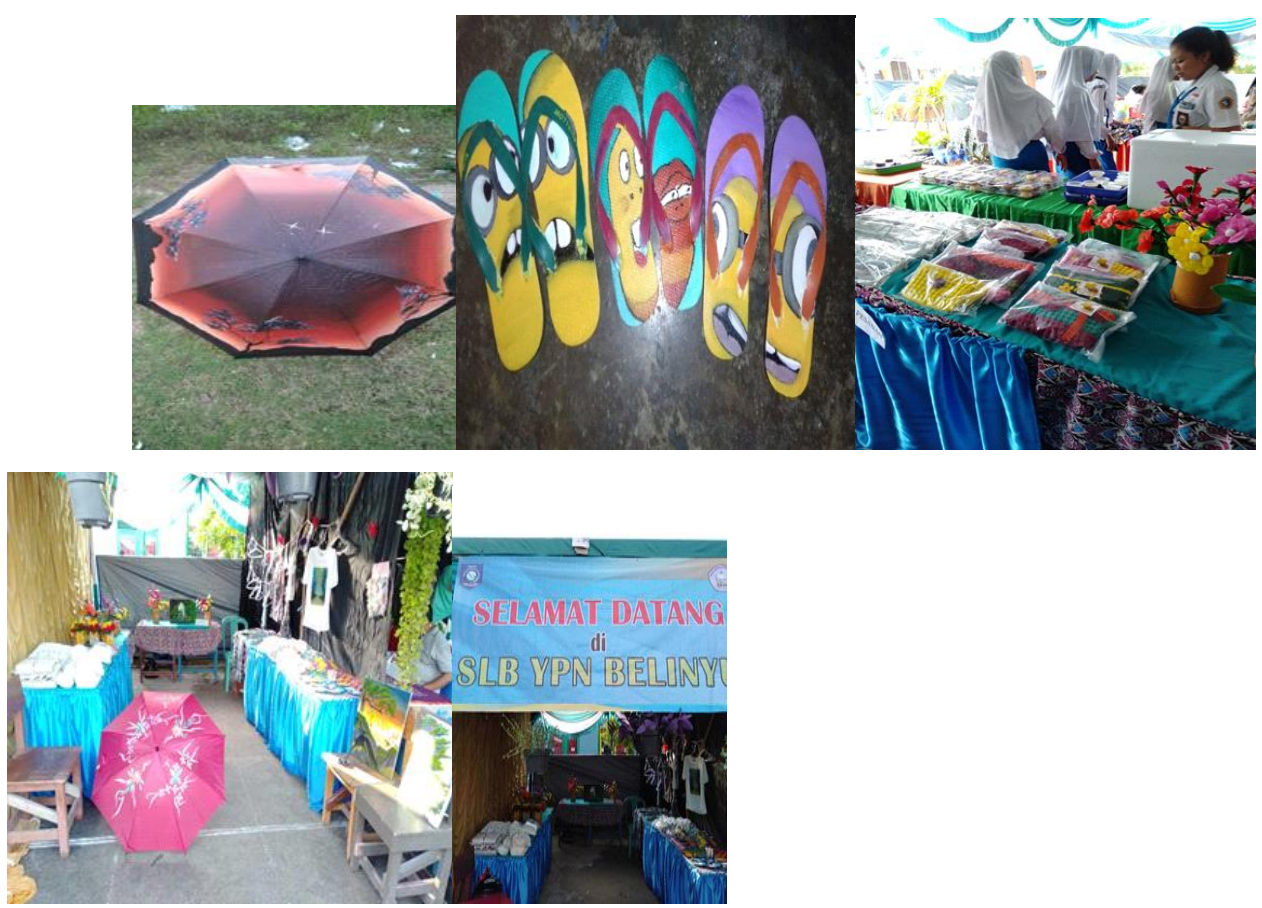

Gambar 1. Hasil Kerajinan Penyandang Disable Sekolah Luar Biasa Air Jukung Belinyu Bangka

Dari gambar di atas maka dapat diuraikan bahwa hasil karya disabilitas seperti payung warna-warni, lukisan,tempat tissue,taplak meja hasil sulaman, sandal jepit dan makanan ringan seperti kue serta celana pendek dari bahan perca merupakan hasil kreasi dari bimbingan salah satu guru yang memberikan pelatihan ketrampilan untuk siswa-siswi SLB dan dihasilkan oleh kelas tuna grahita dan dapat dikembangkan sebagai usaha mandiri sehingga mendapatkan nilai ekonomis dari aktivitas penjualan secara langsung kepada pembeli.

Menurut Rai Utama (2017: 6) pariwisata adalah salah satu mesin penggerak perekonomian dunia yang terbukti mampu memberikan kontribusi terhadap kemakmuran sebuah Negara. Komunikasi pariwisata memiliki komponen dan elemen pariwisata yang di ungkapkan yang mana dengan adanya sumber kekayaan alam tersebut berpotensi untuk melakukan pengembangan produk terhadap masyarakatnya. Pariwisata berkelanjutan menghadirkan semua pihak yang berkepentingan khususnya seluruh anggota masyarakat untuk mengelola sumber dayanya. Keterlibatan,partisipasi masyarakat dalam kegiatan-kegiatan seperti kesenian,budaya, ritual agama serta kuliner khas setempat sangat dibutuhkan dalam upaya pengembangan potensi wisata yang ada di kecamatan belinyu. oleh karena 
itu dengan melibatkan aktivitas ekonomi kreatif dengan mengoptimalkan potensi hasil karya siswa-siswi SLB melalui sektor pariwisata dengan memasarkan hasil karya serta menyediakan produk cindera mata,kuliner, serta mengadakan pasar wisata maka pemanfaatan peluang usaha dapat memberikan keuntungan serta membantu para disabilitas untuk mengembangkan potensi yang mereka miliki.

Melalui pengelolaan berbagai potensi secara optimal maka produk-produk yang sudah dihasilkan diharapkan dapat menarik minat masyarakat/wisatawan lokal untuk membeli dan berpartisipasi melakukan kegiatan ekonomi bagi kesejahteraan para disabilitas. Pendekatan melalui upaya pengembangan potensi produk lokal yang dihasilkan oleh disabilitas siswa-siswi SLB Air jukung harus didukung oleh seluruh lapisan seperti Guru SLB,masyarakat setempat,dinas pariwisata dan pelaku ekonomi lokal di kecamatan belinyu yang mendapatkan manfaat ekonomi dari hasil karya disabilitas.Untuk memastikan bahwa pengembangan potensi produk yang dihasilkan oleh disabilitas memiliki nilai jual adalah adanya penerimaan dan pembelian atas hasil karya tersebut dan dapat dijadikan sebagai pendukung industri pariwisata maka hasil karya atau produkproduk lokal yang telah dihasilkan dapat dipasarkan dan dimanfaatkan sebagai bagian dari industri pariwisata.

Prinsip tentang pengembangan adalah adanya hasil karya yang sudah dihasilkan (produk),sumber daya manusianya, investasi, promosi dan pemasaran.akan sangat menarik apabila pengembangan pariwisata ini dipusatkan pada arah berkelanjutan dengan mengajak partisipasi masyarakat setempat serta memberikan peluang /pemberdayaan ekonomi kreatif yang sudah dihasilkan para disabilitas. Salah satu prinsip dari pengembangan pariwisata yaitu something to buy maka ekonomi kreatif yang dapat dikembangkan adalah pembelian souvenir di daerah wisata.berdasarkan hasil observasi dan wawancara peneliti dengan nara sumber yaitu Ibu Lena mengatakan bahwa,selama ini para disabilitas telah banyak memproduksi kerajinan tangan seperti pembuatan celana pendek dari bahan perca, hanya saja karena keterbatasan modal maka jumlah jahitannya terbatas pada pesanan saja.selain kerajinan tangan ada beberapa kuliner makanan khas setempat yang dihasilkan seperti olahan makanan ringan,kerupuk,keripik dan kue-kue kering.dalam konsep something to buy ini wisatawan lokal tentu saja ketika 
berkunjung ke tempat pariwisata ingin membeli sesuatu atau oleh-oleh yang dapat dibawa pulang,dan ini dapat dijadikan peluang bagi disabilitas untuk memasarkan produk-produk yang sudah dihasilkan.

Untuk mengembangkan potensi produk lokal yang dihasilkan oleh disabilitas pada industri pariwisata dibutuhkan perencanaan dan strategi komunikasi yang baik serta melibatkan para stakeholder seperti investor lokal atau pengelola pariwisata.dengan adanya keterlibatan investor maka produk-produk yang sudah ada dapat diproduksi,dikemas melalui inovasi sehingga produk-produk tersebut dikembangkan dan memiliki nilai jual yang tinggi.selama ini tempat pariwisata di Belinyu belum menyediakan tempat penjualan souvenir dan kuliner makanan khas dalam bentuk kemasan, selama observasi peneliti ke tempat wisata peneliti hanya melihat ditempat wisata disediakan pondok yang masih sangat sederhana terbuat dari kayu seadanya dan atap rumbia dan yang menjuall makanan sejenis empek-empek,otak-otak serta minuman dalam kemasan kaleng,padahal pada saat akhir pekan wisatawan lokal yang datang sangat ramai dan ini memberikan ruang usaha bagi disabilitas sehingga stigma masyarakat bahwa para disabilitas sebagai orang cacat dapat disingkirkan dan kesempatan yang diberikan bukan karena rasa kasihan atas keterbatasan fisik bahwa disabilitas patut dikasihani tetapi lebih kepada mengembangkan potensi dan ketrampilan yang mereka miliki. Hasil karyanya menjadi nilai jual dan membuktikan bahwa merekapun dapat berkonstribusi dibidang usaha pariwisata. Apabila disediakan ruang usaha bagi disabilitas maka akan memberikan dampak positif bagi kesejahteraan disabilitas dan peluang kerja serta mendorong berkembangnya industri pariwisata yang ada di Belinyu.

Pengembangan pariwisata berkonstribusi memberikan peluang usaha baru dan membuka lapangan pekerjaan bagi masyarakat khususnya penyandang disabilitas. Kegiatan pariwisata dapat menarik masyarakat untuk datang karena biasanya pada objek pariwisata ada sesuatu yang menarik dan spesifik sehingga wisatawan menginginkan sesuatu yang dapat dilihat dan dibeli.Sesuatu yang unik itu dapat berupa souvenir,cinderamata,produk-produk lokal yang menjadi ciri khas daerah wisata seperti kuliner, sehingga pemenuhan kebutuhan liburan wisata dapat terpenuhi dan selain itu juga kegiatan ekonomi dapat terjadi pada daerah wisata 
tersebut. Melalui kegiatan ekonomi tersebut maka disabilitas dapat menyediakan serta mempromosikan produk yang sudah dihasilkan kepada masyarakat apalagi bila disediakan kios untuk berjualan sehingga varian-varian produk yang dihasilkan dapat dipajan, menghasilkan transaksi antara pengunjung wisata dan disabilitas,Hal ini akan menarik minat pengunjung wisata untuk kembali berkunjung karena ketertarikan akan souvenir pariwisata tersedia di tempat destinasi wisatanya.

Dengan adanya peluang usaha disektor pariwisata diharapkan masyarakat kecamatan belinyu dapat memilih alternative lain dalam hal mata pencaharian kerja selain sektor pertambangan. Salah satu strategi pemerintah daerah Babel untuk mengubah mindset masyarakatnya yang mengandalkan sektor pertambangan maka dibidang sektor pariwisata merupakan pilihan yang sedang dikembangkan. Tentu saja bukan persoalan yang mudah untuk mengubah pola pikir yang sudah menjadi tradisi masyarakat babel karena itu butuh partisipasi pihak terkait dalam mempromosikan sektor wisata serta memasarkan produk-produk lokal yang berpontensi menjadi produk yang memiliki nilai jual.

Hasil observasi peneliti ke tempat pariwisata pantai levar dan pantai penyusuk, belum ada yang menjual souvenir berupa kerajinan tangan dan makanan khas kuliner hasil olahan seperti kerupuk,keripik dan makanan kemasan. Selama ini hanya penjual musiman yang menjajakan makanan dan minuman ringan sebatas akhir pecan saja, sehingga wisatawan harus membawa makanan sendiri disebabkan keterbatasan pilihan produk yang ditawarkan di daerah wisata tersebut. Melihat kondisi ini maka peneliti menyimpulkan bahwa produk-produk yang telah dihasilkan oleh penyandang disabilitas dapat dipasarkan pada pasar wisata dan tentu saja dapat dikembangkan melalui inovasi sehingga produk ini dapat memberikan manfaat ekonomi serta dapat diproduksi dengan jumlah banyak.peluang usaha yang dapat dikembangkan sesuai dengan kemampuan atau ketrampilan yang dimiliki dan yang sudah dihasilkan adalah berupa cindera mata, gantungan kunci,tempat tissue dari bahan daur ulang, kaos pantai sablon, celana pantai dari bahan perca, serta makanan khas /kuliner dalam bentuk kemasan sehingga dapat dibawa pulang oleh wisatawan sebagai oleh-oleh.

Melalui kegiatan pariwisata maka pengembangan potensi produk local yang dihasilkan penyandang disabilitas dapat diwujudkan serta memberikan peluang 
lapangan kerja bagi disabilitas dan mereka dapat mandiri untuk memenuhi kebutuhan serta kesejahteraannya. Selain itu dengan aktivitas positif ini dapat mengubah pola pikir masyarakat yang beranggapan bahwa disabilitas tidak dapat bekerja pada sektor formil ternyata dapat memberikan konstribusi di sektor pariwisata walaupun mereka memiliki keterbatasan secara fisik.oleh karena itu peran dan partisipasi dinas pariwisata, investor,pengelola wisata,guru SLB serta masyarakat sangat dibutuhkan dalam memberikan kesempatan bagi disabilitas untuk mengembangkan potensi yang mereka miliki dengan memberikan ruang yang seluas-luasnya bagi mereka.

\section{SIMPULAN}

Pengembangan potensi produk lokal yang dihasilkan oleh penyandang disabilitas dapat dikembangkan melalui industri pariwisata dengan memberikan kesempatan bagi disabilitas untuk menghasilkan, memasarkan serta mempromosikan produk-produk yang menjadi andalan wisata melalui pasarwisata sehingga menjadi produk yang diminati oleh wisatawan lokal dan luar.

Selama ini belum ada upaya yang maksimal dari stakeholder, masyarakat untuk memasarkan produk yang dihasilkan oleh disabilitas padahal produk yang dihasilkan memiliki potensi nilai jual dan dapat membuka kesempatan sebagai usaha untuk kemandirian mereka.

Varian-varian produk lokal harus dikemas dengan baik melalui brand dan dikembangkan melalui inovasi serta menyediakan pasarwisata untuk mempromosikan produk yang sudah ada sehingga menjadi produk unggulan dan dapat menarik wisatawan lokal untuk membeli.

\section{Saran}

Peran, partisipasi stake holder, masyarakat. Guru SLB yang memberikan ketrampilan sangat dibutuhkan untuk memberikan kesempatan kepada disabilitas untuk mengembangkan potensi diri mereka agar dapat memberikan konstribusi di sektor pariwisata dengan mempromosikan produk-produk unggulan yang telah dihasilkan agar diminati masyarakat wisata.

Penyandang disabilitas diberikan ruangan usaha agar mereka dapat berpartisipasi dalam kegiatan pariwisata serta bersikap mandiri dalam memenuhi kesejahteraan hidup dan terus diberikan pembinaan berupa pelatihan, ketrampilan 
dan manajemen pemasaran serta promosi agar mereka terus meningkatkan hasil karya yang memiliki nilai ekonomis serta berinovasi sehingga siap mengha dapi persaingan dibidang pariwisata.

Mengupayakan kemitraan dalam hal kerjasama dari berbagai pihak seperti investor, pelaku usaha pariwisata untuk merencanakan, membuat strategi pemasaran atau berupa workshop kepada penyandang disabilitas agar dapat meningkatkan penjualan varian-varian produk yang sudah ada serta dapat mengembangkan sektor pariwisata daerah.

\section{Ucapan Terimakasih}

Peneliti mengucapkan terimakasih kepada reviewer para Dosen STKIP PGRI Situbondo atas kritik dan sarannya pada penulisan penelitian ini, serta ucapan terima kasih kepada para Guru dan siswa-siswi SLB Air Jukung Belinyu atas kesediaannya telah menerima Peneliti untuk melakukan observasi dan wawancara, memberikan data-data dan informasi untuk mendukung penelitian ini.

\section{DAFTAR RUJUKAN}

Afrizal. (2017). Metode penelitian kualitatif: sebuah upaya mendukung penggunaan penelitian kualitatif dalam berbagai disiplin ilmu. Rajawali Pers.

Arman. (2020). Ekonomi Lokal \& Pembangunan Pedesaan Di Dusun Berambai Kalimantan Timur. Journal Society, 8(2).

Bungin, B. (2015). Komunikasi Pariwisata,Pemasaran dan Brand Destinasi. Prenada Media Group.

Kasmir. (2018). Kewirausahaan. Rajawali Pers.

Lewa, A. H. (2018). Pengembangan Masyarakat Berbasis Kewirausahaan Untuk Meningkatkan Pariwisata Dan Budaya Di Desa Wisata Kandri Kota semarang. Lite, 14(1).

Moelong, L. J. (2017). Metodologi Penelitian Kualitatif. Remaja Rosdakarya. Muljadi, A. (2009). Kepariwisataan dan Perjalanan. PT. Raja Grafindo Persada. Oktavania, W. P. (2019). Pengaruh Pemasaran Langsung dan Promosi Penjualan Terhadap Keputusan Pembelian Produk Wardah Exclusive Matte Cream Di Tokopedia. Expose: Jurnal Ilmu Komunikasi, 2(1).

Rusyidi, B., \& Muhammad Ferdryansah. (2018). Pengembangan Pariwisata 
Berbasis Masyarakat. Focus: Jurnal Pekerjaan Sosial, 1(3).

Sanam, S. R., \& I Made Adikampana. (2017). Pengembangan Potensi Wisata Pantai Laisana sebagai Pariwisata Berkelanjutan Di Kota Kupang Provinsi Nusa tenggara Timur. Jurnal Destinasi Pariwisata, 2(1).

Sedarmayanti. (2018). Pembangunan \& Pengembangan Pariwisata. Refika Aditama.

Soritua, Y. (2015). Analisis Peran Sektor Pariwisata Menjadi Pendapatan Utama Daerah. Jurnal Ilmu Manajemen Dan Akuntansi, 3(2).

Sudarsono, J. G. (2017). Pengaruh Visual Merchandising terhadap impulse buying melalui positive emotion pada Zara Surabaya. Jurnal Manajemen Pemasaran, 11(1).

Universitas Brawijaya. (2014). Buku Panduan Aksebilitas Layanan. Pusat Studi Layanan Disabilitas.

Wardhani, R. S., \& Valeriani, D. (2016). Green Tourism Dalam Pengembangan Pariwisata Bangka Belitung. Prosiding Seminar Nasional INDOCOMPAC, $0(0)$, $275-286$. http://jurnal.bakrie.ac.id/index.php/INDOCOMPAC/article/view/1608 